\title{
IS LOMCE A STEP FORWARD OR BACKWARD?
}

\author{
Ana Campos and Natalia Lara. Universidad de Granada.
}

Artículo dirigido por: Katia Caballero. Departamento de Didáctica y Organización Escolar. Universidad de Granada

Fecha de recepción: 31 de enero de 2014.

Fecha de revisión: 19 de marzo de 2014.

Fecha de aceptación: 11 de abril de 2014.

\begin{abstract}
With the new approval of LOMCE, some changes have been done that affect the comprehensiveness and autonomy of schools. This article will be centered on the new principal's role and the flexibility of the trajectories. With this reform the principal assumes more autonomy and authority; we will explain why it is a synonym of inequality. Moreover, the aim of this flexibility of trajectories is to separate in the fourth $4^{\text {th }}$ course of Secondary Education those students who want to study from those who are looking forward to working.
\end{abstract}

Keywords: Equity, comprehensiveness, principal, educational reform

\section{Resumen}

Con la aprobación de la LOMCE, se han hecho algunos cambios que afectan la comprensividad y autonomía de los colegios. Este artículo se centra en el nuevo papel del director y en la flexibilización de trayectorias. Con esta reforma, el director asume más autonomía y autoridad, explicaremos por qué esto es sinónimo de desigualdad. Además, el propósito de esta flexibilización de las trayectorias es separar en $4^{\circ}$ curso de Educación Secundaria aquellos estudiantes que quieren estudiar de aquellos que deseen empezar ya por la vía laboral.

Palabras clave: Igualdad, comprensividad, director, reforma educativa.

\section{INTRODUCTION}

LOMCE, The Organic Law for the Improvement of the Educational Quality (2013), tries to improve the educational quality of our country by making some changes that have generated the rejection of the educational community. With the approval of this new educational law, some misgivings arise at the perspective of any change in our educational system. As Bolívar (2012) states the successive educational reforms have not truly modified our schools and do not actually favor the quality of education because it would produce an unstable system. If these changes directly affect (and, in this case, they do affect) the equity and comprehensiveness of our educational system, then, the first and most important question should be: In which way does this reform affect students' future? 
Moreover, it seems that the main objective of this law is to remove, bit by bit, autonomy to schools and a very good example is the educational leadership and the new role of the principal. Here, the main fear of the educational community is that School Council is losing authority whereas autonomous communities are gaining it.

\section{EDUCATIONAL LEADERSHIP}

Educational leadership is an essential factor for a successful educational system. For this reason, a lot of national and international studies and research have focused on this topic. TALIS is one of these international documents which examines many aspects of European schools and offers a comparison between them.

It is interested in leadership because it is one of the most influential factors in learning after teaching. "The lack of strong relations between school leadership behaviour and teachers' practices, beliefs and attitudes... is an interesting finding. It is consistent with other research that shows the impact of school leadership to be indirect and mitigated through the actions of teachers and others (TALIS, 2009:204).

The document provides useful information for understanding Spain's leadership and shows us the differences between Spain and many other countries. In the following graph (see table 1) presented in TALIS (2009: 197) we can see how Spain is one of the countries with the lowest average in the use of instructional leadership, such us Austria and Estonia, but it also has principles that focus on management style. On the other hands, countries like Hungary, Poland and Slovenia are notably above the TALIS mean (2009:197).

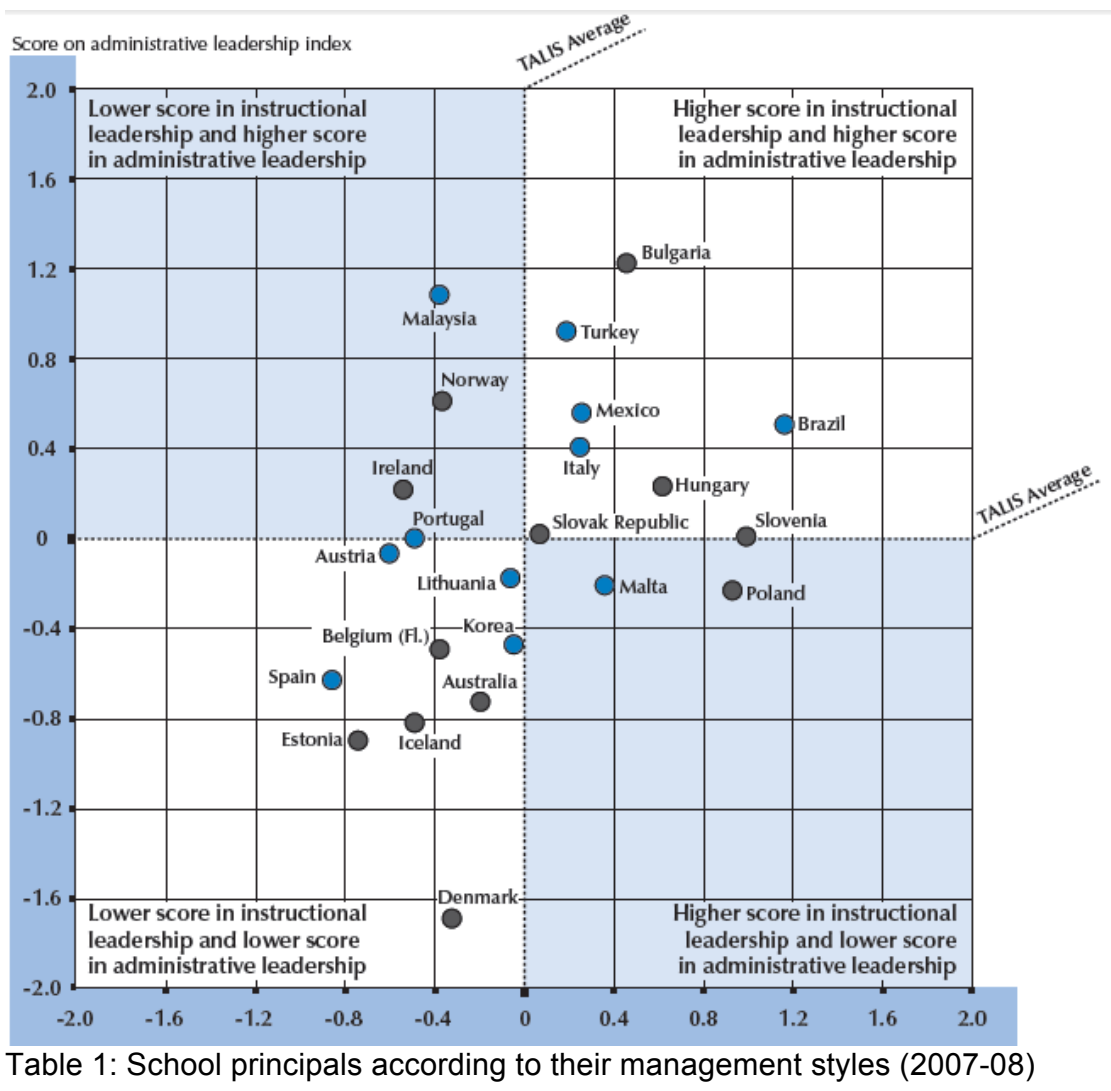

Countries in gray have a higher than average principal involvement in decision making, while countries in blue have a lower than average involvement. Source: OECD, TALIS Database. 


\section{The principal, an essential part of the system}

In Spain there have been many reforms and counter-reforms during the last 45 years in the field of education (Grau, 2012). The principal is responsible for coordinating and managing the school; for this reason, there have been many of these laws that have tried to find the most effective model of leadership. Between them we could find LOGSE (1990), which provides more school's autonomy; LOPEG (1995) a law about school's government and management; and LOCE (2002) which was never implemented. The society is aware that leadership is a very complex process and we should find the best system to manage it.

The recent law modifies the Article 119.1 of LOE and removes the capacity of the management of Educational Communities. The school director shall be elected by the local Administration, rather than be elected by the Educational Community (Vallejo, 2012). Until now, the director was chosen by the school council. The school council was formed by teachers, students, parents, and administration and services staff. With LOMCE, the director is selected by a commission composed of at least $50 \%$ of members of Public Administration and less than $50 \%$ by the Educational Community. We can see how in this law the role of teachers will be less important and how the process of making decisions takes place in a meeting of politicians.

According to this change, school council transfers its competences to the principal and also some new functions are added to the previous in LOE (see Table 2):

\begin{tabular}{|c|c|c|}
\hline \multicolumn{3}{|c|}{ 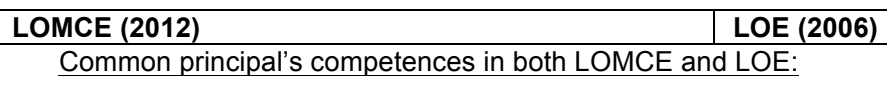 } \\
\hline Common pri & \multicolumn{2}{|c|}{$\begin{array}{ll}\text { A. } & \text { Representation of the center. } \\
\text { B. Direct and coordinate. } \\
\text { C. Pedagogical direction. } \\
\text { D. Enforce laws. } \\
\text { E. Chief of workers. } \\
\text { F. Promote coexistence. } \\
\text { G. Promote collaboration. } \\
\text { H. Promote evaluation. } \\
\text { I. Chairing academic events. } \\
\text { J. Perform contract works. } \\
\text { K. Suggest new board members. } \\
\text { L. Approve projects and standards. }\end{array}$} \\
\hline \multicolumn{3}{|c|}{ New principal's competences in LOMCE: } \\
\hline \multicolumn{3}{|c|}{ To approve projects and school rules. } \\
\hline \multicolumn{3}{|c|}{ To approve the general annual program. } \\
\hline \multicolumn{3}{|c|}{ To obtain additional resources. } \\
\hline \multicolumn{3}{|c|}{ To obtain advertising } \\
\hline \multicolumn{3}{|c|}{ To funding from private entities } \\
\hline \multicolumn{3}{|c|}{ Decisions about students' admission. } \\
\hline Collaboration w & nistration & \\
\hline
\end{tabular}

Table 2: Principal's competences in both LOMCE and LOE laws 
The functions of the school council shall be of consultation but not of decision-making (Morata, 2012). LOMCE gives the director the power to decide, among other things, which students are admitted and which teachers take part of the staff. As we explain in the previous paragraph, the selection of the director is in the hands of Public Administrations so School Council is, nowadays, without any decision-making power in anything related to the school's future. However, in practice, the future of the school is in the hands of those who know it well, not in those who will be in the power this year and the following year they will deal with environmental issues, for example.

There is no document, authors or theories which guarantee these approaches. We cannot know if having a representative of the educative administration as a principal, education will be improved. The current government, Partido Popular, claims to follow the OECD report (2008) "Improving School Leadership"; however, this document does not advise any of the reforms proposed in this law (San Fabián and Bolívar, 2013).

This hierarchical model, where the principal gets the majority of competences, encourages recentralization of power. This does not provide the educational community participation, it is authoritarian (Morata, 2012).

Eugenio Nasarre, a Council Member of Partido Popular (PP), says that with this reform the principal's role assumes autonomy and authority. However, Mario Vedera, Secretary of Education of PSOE, affirms that LOMCE removes autonomy to schools when it proposes principal selection process to be done by the Autonomous Community.

As we can find in the article 122.4 of LOMCE, the principal decides if interim teachers work or not in his/her school and he/she chooses the teacher staff. Now is the time to refer to the so-called "project of quality". LOMCE gives the principals the possibility to present "projects of quality" where they can decide which teachers are accepted or rejected and this decision will be made without taking into account any experience, training and merits. Remembering that these new principal have been chosen by Public Administrations so, what type of teacher staff will be in our schools?

With all this information, it is clear that we need a fast and effective change in our educational system but, perhaps, the measures proposed in this law will not be the most appropriated.

We need a system that allows an education based on equality and quality. To achieve this it is vital to have a team of good prepared teachers, whose personal training and experience were valued and provide a fair and quality education. If the school's administration is in the hands of our government's friends that are not in contact with the real life of schools we will never be the results we seek.

\section{FLEXIBILITY OF THE TRAJECTORIES}

Another controversial topic that comes with this new reform is the flexibility of trajectories, this means, schools will offer different types of itineraries depending on the type of students -selected previously by the principal- that the school has. As a result, each student will achieve different objectives, according to their "talent".

Then, it is necessary to talk about the change of the fourth grade of Secondary Education into an introductory grade of two itineraries: the Professional and the Academic one, that is, the pass to two closed lines: Professional Training and Higher Secondary Education. 
The fourth course of Mandatory Secondary Education will have an illustrative nature, that can be studied either for the initiation to the Higher Secondary Education (academic teaching), or to the initiation of the Professional Training (applied teaching). It is important to highlight the distinction between "academic" and "applied" curriculum because, according to Bolívar \& San Fabián (2013:1), "the separation between thinking and doing reproduces a social structure that divides humans into those who plan and those who execute".

But characteristics and requirements to enter into the Professional Training have also changed. Previously, with LOE (2006) it was required to be more than 16 years and they must have finished their studies of Compulsory Secondary Education (Artículo 15 de la Ley Orgánica de Educación 2/2006, de 3 de mayo), so that they have their Secondary Education title. Nevertheless, with the approval of LOMCE, students who are 15 years old that have, at least, completed the first cycle of Compulsory Secondary Education will be able to access the Basic Professional Training, known before as P.C.P.I (Artículo 41 de la Ley Orgánica 8/2013, de 9 de diciembre, para la mejora de la calidad educativa). This means that anticipating the election, a considerable part of students will only achieve a simple Studies Certificate or, at best, a Basic Professional Training, since the proposed learning improvement programs do not allow the direct access to the actual title of Graduated in Secondary Education (Colectivo Lorenzo Luzuriaga, 2012).

What's more, up to now, if it was detected that a student could not reach the title of Secondary Education due to the student's difficulties (he/she wants to succeed, but because of any difficulty he cannot), he entered in a program named Curricular Diversification addressed the third and fourth course of Compulsory Secondary Education. In this program, subjects and methodology were adapted to help them to achieve this title. With LOMCE, Curricular Diversification is now called "Program to the improvement of learning and performance" (Programa de Mejora del Aprendizaje y el Rendimiento: P.M.A.R.), which affects $2^{\text {nd }}$ and $3^{\text {rd }}$ course of Secondary Education. The huge difference between LOE and LOMCE in this aspect is that when a student finishes P.M.A.R., he/she will be incorporated into the ordinary $4^{\text {th }}$ course of E.S.O. to get the title of graduated (Vallejo, 2012). Students who had done this program have been studying for two years every subject in a lower level, so, as we see it, it would be very difficult for him to reincorporate into the ordinary $4^{\text {th }}$ course. So, another option for that student would be to abandon E.S.O. and to be incorporated into the Basic Professional Training that, as we said before, does not give the student the title of Graduated in Secondary Education.

What this proposal basically implies is the segregation of the students at the age of 14 years, who will be obligated to choose between continuing studying or working. This will increase the level of indecision among students and those students whose families have a lower economical level would opt for the professional itinerary (Soy Pública Corporation, 2012). Besides, it will be an irrevocable decision that will affect those that once they had chosen an itinerary; they want to change to the other one. But the real and concerning matter is that the segregation and differences between those students who go to the Professional way and those who prefer to continue their studies by the Academic itinerary will increase in a considerable manner. If there was a difference before between those of "letters" and those of "sciences", this law is now creating a new type of distinction between the "clever" ones, and those that are only useful to work. 
Comprehensive school

With LOMCE we are moving farther away from the model of comprehensive school, which looks for the retardation of the separation of students in different branches, besides providing a polyvalent teaching (Humanistic, Scientific and ProfessionalTechnical) to every student. It is proved that in countries in which teaching is common until 16 years old, students obtain better results (Morata, 2013). For example, Finland is the country with the best educational quality of Europe and Secondary Education is common to every student.

\section{CONCLUSION}

One more time our education system is facing another alteration. This time, as viewed by the most knowledgeable in this subject, we are confident that affect equity and comprehensiveness.

Educational leadership is a fundamental pillar for the whole educational system to work. According to LOMCE and in relation to this topic, educational leadership gains autonomy and power within school decisions. The change of the principal's competences gives to him/her the freedom of selecting the appropriated students that fit in the school conditions and choosing the teacher staff. Obviously, the selection of specific students (which in the majority of the times correspond to the better ones), do not promote equity and inclusion in our schools. The unique factor that would solve this negative situation would be the possibility of students to choose their school, attending to their special and specific needs.

With the flexibility of itineraries and the advancement to the age of 14 of the selection of either continuing their studies or working, students will be more undecided. Apart from the indecision and the mistakes that students will probably make by choosing their future at such an early age, with this educational reform we are, little by little, moving away from the model of comprehensive school that others countries, such as Finland, follow. It is proved that in those countries, the age of leaving school is higher, and this is what we should try. If this arrangement has so good results in that country, why it could not work here in Spain?

Finally, with the approval of LOMCE and as the law cites: "Education is conceived as an engine that promotes the competiveness of the economy, a bet to get competitive advantages in the global market". If we think about this in a deeper way, we can come to the conclusion that the real aim of this reform is to get people less qualified, so they will have jobs in worst working conditions and with lower salaries.

If we take a look to all the important points of this article, we can see that the majority of the new reforms may have negative consequences on our educational system and it means a step backward. Nevertheless, we are talking about something that has not had time to be implemented. We need to wait to see its results, and to analyze whether changes obtained are a step forward or backward in the evolution of the educational system. To finalize, we definitely believe that success is in the direction of equality and comprehensiveness.

\section{REFERENCES}

Bolívar, A. (2012). Hastiados de reformas educativas. Revista Escuela, 3956, 37. 
Bolívar, A. \& San Fabián, J. (2013). La LOMCE, ¿una nueva ley para mejorar la calidad educativa? Organización y Gestión Educativa, 1, 7-11.

Colectivo Lorenzo Luzuriaga. (2012). Diez preguntas para el ministro Wert. Recuperado el 10/05/2013 de: http://www.colectivolorenzoluzuriaga.com/PDF/Diez $\% 20$ preguntas $\% 20 a \% 20 \mathrm{We}$ rt.pdf

Collado, I. (2012). El director escolar: competencias, funciones y características. Programa de mejora de centro. Recuperado el 11/05/2013 de http://dspace.ceu.es/bitstream/10637/5319/1/TFM_Collado_Navarro,\%20lsaac Jos\%C3\%A9.pdf

Grau, J. (2012). Las siete leyes orgánicas que han regulado la enseñanza media en democracia, una a una. Recuperado el 12/01/2014 de http://www.abc.es/20120922/sociedad/abci-leyes-educacion-reforma-wert201209212205.html

Ley Orgánica de Educación 2/2006, de 3 de mayo (BOE n 106, 4-5-2006)

Ley Orgánica 8/2013, de 9 de diciembre, para la Mejora de la Calidad Educativa. (BOE $\left.n^{\circ} 295,10-12-2013\right)$.

Morata, J. (2013). Por otra política educativa. Madrid: Ediciones Morata.

OECD (2009). Creating Effective Teaching and Learning Environments: First Results from TALIS. Paris: OECD. Recuperado el 07/08/2009 de http://www.oecd.org/dataoecd/17/51/43023606.pdf

Soy Pública corporation (2013). Anteproyecto de la LOMCE analizado. Recuperado el 10/05/2013 de http://soypublica.wordpress.com/2012/10/08/lo-que-esconde-lalomce-analisis-del-anteproyecto-de-ley-de-educacion/

Vallejo, M. (2012). Lo que traerá la L.O.M.C.E. Recuperado el 15/05/2013 de http://www.fundacionideas.es/publications/articles/5825 